\title{
Extracellular Formation of Alanine by Anaerobes ${ }^{\dagger}$
}

\author{
Motoyoshi Hongo, Boon Hui GAN ${ }^{1 *}$ and Masaru UyedA ${ }^{2 *}$ \\ Laboratory of Applied Microbiology, Department of Agricultural Chemistry, \\ Kyushu University, Fukuoka, Japan \\ Received March 18, 1974
}

\begin{abstract}
The possibility of extracellular formation of amino acids by anaerobes was investigated. In general, anaerobes were able to produce 20 to $50 \mathrm{mg}$ of alanine per $\mathrm{dl}$ of medium extracellularly. Clostridium saccharoperbutylacetonicum, the anaerobic bacterium for acetonebutanol fermentation, accumulated $100 \mathrm{mg}$ of alanine per $\mathrm{dl}$ of medium containing $5 \mathrm{~g}$ of glucose, $1 \mathrm{~g}$ of ammonium acetate, $0.1 \mathrm{~g}$ of potassium dihydrogen phosphate, $0.04 \mathrm{~g}$ of magnesium sulfate, $0.001 \mathrm{~g}$ of ferrous sulfate, $1 \mu \mathrm{g}$ of biotin, $0.1 \mathrm{~g}$ of yeast extract and $1 \mathrm{~g}$ of calcium carbonate in tap water.

Relationships between alanine formation and solvent yields or sporulation were investigated. Spore formation was not active in the medium for alanine formation and yield of acetone increased in this medium.
\end{abstract}

Bacteria used in all kinds of amino acid fermentation today are aerobes. The purpose of the present paper is to investigate the possibility of the extracellular formation of amino acids by anaerobes. Even in anaerobes, cellular proteins and accordingly amino acids, their constituents, are synthesized from glucose and nitrogen source in the medium. Realizing this point early, the authors have studied this subject since 1962. Aerobacter aerogenes No. 505 isolated from a specimen of soil obtained from a field near our University in Hakozaki, Fukuoka produced only alanine under anaerobic conditions as described before. ${ }^{11}$

Nioman et al. ${ }^{21}$ reported in 1947 that the resting cells of anaerobes, $\mathrm{Cl}$. acetobutyricum, $\mathrm{Cl}$. saccharobutyricum and $\mathrm{Cl}$. sporogenes were able to utilize sodium pyruvate and ammonium phosphate at $\mathrm{pH} 7.0$ to produce alanine, aspartic acid and glutamic acid. Extracellular formation of amino acids in the culture broth by anaerobes was not found in any further report. This paper deals primarily with alanine

+ Extracellular Formation of Amino Acids by Anaerobes. Part I.

1* Present address; 44 New Market Road, Mallacca, Malaysia.

2* Present address; Laboratory of Medicinal Microbiology, Faculty of Pharmaceutical Sciences, Kumamoto University, Japan. formation by a strictly anaerobic bacterium, Clostridium saccharoperbutylacetonicum.

\section{METHODS}

The anaerobic bacterium used in this work was $\mathrm{Cl}$. saccharoperbutylacetonicum reported by Hongo $^{31}$ as an acetone-butanol-producing bacterium. This strain was kept as spore stocks in sand. Bacterial culture was prepared by the method presented in the previous paper.4 One hundred $\mathrm{ml}$ of the culture, incubated overnight at $30^{\circ} \mathrm{C}$ in the TYA (Tryptone-Yeast extractAmmonium acetate $)^{5\}}$ medium, were centrifuged at $9000 \mathrm{rpm}$ for $5 \mathrm{~min}$. Cells were collected and suspended in $10 \mathrm{ml}$ of the medium for alanine formation. This suspension was used as seed, that is, $0.1 \mathrm{ml}$ of it was used to inoculate each tube containing $10 \mathrm{ml}$ of the medium for alanine formation. All tubes were fastened with cotton plugs and kept at $30^{\circ} \mathrm{C}$ without using anaerobic jars.

Alanine was assayed by the method of Watanabe et al. ${ }^{6)}$ Cell growth was observed by measuring the optical density at $660 \mathrm{~nm}$. Residual glucose was measured by micro-Bertrand's method. ${ }^{71}$ ORP was measured by the method presented in the previous paper.8)

\section{RESULTS AND DISCUSSION}

Examination of the medium for alanine formation

The medium was examined for alanine formation. Concentrations of glucose and am- 
monium acetate were checked as shown in Table I. The cell growth was better in the presence of $0.5 \%$ ammonium acetate than in $1 \%$ ammonium acetate. However, alanine formation was maximum with $1 \%$ ammonium acetate and $5 \%$ glucose from paper chromatographic observation. But even in this case, the consumption of glucose was incomplete. In order to promote its consumption and carry out the fermentation smoothly, $0.1 \%$ of the materials shown in Table II was added to the medium

Table I. Effect of Ammonium Acetate and Glucose on Cell Growth

Growth after $48 \mathrm{hr}$ culture; $++>0.5$ O.D., $0.5>+>0.1$ O.D., $-<0.1$ O.D.

Basal composition; $0.1 \mathrm{~g}$ of $\mathrm{KH}_{2} \mathrm{PO}_{4}, 0.04 \mathrm{~g}$ of $\mathrm{MgSO}_{4} \cdot 7 \mathrm{H}_{2} \mathrm{O}, 0.001 \mathrm{~g}$ of $\mathrm{FeSO}_{4} \cdot 7 \mathrm{H}_{2} \mathrm{O}, 1 \mu \mathrm{g}$ of biotin in $100 \mathrm{ml}$ of tap water. $0.1 \mathrm{~g}$ of $\mathrm{CaCO}_{3}$ sterilized separately was added to each tube $(10 \mathrm{ml})$.

\begin{tabular}{cccccc}
\hline $\begin{array}{c}\text { Ammonium acetate } \\
(\%)\end{array}$ & 2 & 3 & 4 & 5 & 10 \\
\hline 0.5 & ++ & ++ & ++ & ++ & - \\
1.0 & + & + & + & + & - \\
\hline
\end{tabular}

Table II. Factors Necessary for Complete CONSUMPTION OF GluCOSE

Basal composition of medium is the same as in Table I except $5 \mathrm{~g}$ of glucose and $1 \mathrm{~g}$ of ammonium acetate.

\begin{tabular}{lcc}
\hline $\begin{array}{c}\text { Substance added } \\
(0.1 \% \text { each })\end{array}$ & $\begin{array}{c}\text { Growth at } \\
18 \mathrm{hr} \\
(\text { O.D. at 660 }\end{array}$ & $\begin{array}{c}\text { Glucose } \\
\text { consumed } \\
(\mathrm{g} / \mathrm{dl})\end{array}$ \\
\hline None (control) & 0.09 & 1.5 \\
Casamino acid & 0.43 & 3.2 \\
Corn steep liquor & 0.24 & 1.7 \\
Tryptone & 0.39 & 1.5 \\
Yeast extract & 0.53 & 5.0 \\
\hline
\end{tabular}

mentioned above. When yeast extract was added to the medium, it showed the highest growth and best utilization of glucose. The optimal concentration of yeast extract was checked as shown in Table III. Adding 0.1 to $0.3 \%$ yeast extract to the medium was considered to be the best for alanine formation.

The $\mathrm{C} / \mathrm{N}$ ratio in the medium for the best formation of alanine was examined as shown in Table IV. This bacterium could not grow in the medium containing $10 \%$ glucose. In

Table III. Effect of Concentration of Yeast Extract on Alanine Formation

Basal composition of medium is the same as in Table II.

\begin{tabular}{ccc}
\hline $\begin{array}{c}\text { Yeast extract } \\
(\%)\end{array}$ & $\begin{array}{c}\text { Glucose consumed } \\
(\mathrm{g} / \mathrm{dl})\end{array}$ & $\begin{array}{c}\text { Alanine formed } \\
(\mathrm{mg} / \mathrm{dl})\end{array}$ \\
\hline 0.05 & 5.0 & 45 \\
0.1 & 5.0 & 102 \\
0.3 & 5.0 & 103 \\
0.5 & 5.0 & 53 \\
\hline
\end{tabular}

general, addition of $1 \%$ ammonium acetate to the medium showed better alanine formation than that of $0.5 \%$. The best yield of alanine of initial glucose was obtained in the medium containing $5 \%$ glucose and $1 \%$ ammonium acetate. Accordingly, the medium for alanine formation was decided as follows; $5 \mathrm{~g}$ of glucose, $1 \mathrm{~g}$ of ammonium acetate, $0.1 \mathrm{~g}$ of potassium dihydrogen phosphate, $0.04 \mathrm{~g}$ of magnesium acetate, $0.001 \mathrm{~g}$ of ferrous sulfate, $1 \mu \mathrm{g}$ of biotin, $0.1 \mathrm{~g}$ of yeast extract and $1 \mathrm{~g}$ of calcium carbonate in $100 \mathrm{ml}$ of tap water. As shown in Table $\mathrm{V}$, various nitrogen

Table IV. Influence of the C/N Ratio on Alanine Formation

\begin{tabular}{ccccccc}
\hline $\begin{array}{c}\text { Glucose } \\
(\%)\end{array}$ & $\begin{array}{c}\mathrm{NH}_{4} \text {-acetate } \\
(\%)\end{array}$ & $\begin{array}{c}\text { Final } \\
\mathrm{pH}\end{array}$ & $\begin{array}{c}\text { Residual } \\
\text { glucose }(\%)\end{array}$ & $\begin{array}{c}\text { Growth } \\
\text { at } 18 \mathrm{hr}\end{array}$ & $\begin{array}{c}\text { Alanine } \\
(\mathrm{mg} / \mathrm{dl})\end{array}$ & $\begin{array}{c}\% \text { yield of } \\
\text { initial glucose }\end{array}$ \\
\hline 2.5 & 0.5 & 6.6 & 0 & 0.64 & 22 & 0.9 \\
2.5 & 1.0 & 6.8 & 0 & 0.60 & 30 & 1.2 \\
5.0 & 0.5 & 6.4 & 0 & 0.57 & 54 & 1.1 \\
5.0 & 1.0 & 6.4 & 0 & 0.39 & 75 & 1.5 \\
7.5 & 0.5 & 6.6 & 0 & 0.38 & 72 & 1.0 \\
7.5 & 1.0 & 6.2 & 1.7 & 0.30 & 80 & 0 \\
10.0 & 0.5 & 5.8 & 10.0 & 0.04 & 0 & 0 \\
10.0 & 1.0 & 5.8 & 10.0 & 0.08 & 0 & 0 \\
\hline
\end{tabular}


Table V. Effect of Various Nitrogen Sources on Alanine Formation

Concentration of nitrogen source; each $0.2 \mathrm{~g}$ as nitrogen/dl of medium was added.

\begin{tabular}{|c|c|c|c|}
\hline Nitrogen source & $\begin{array}{c}\text { Final } \\
\mathrm{pH}\end{array}$ & $\begin{array}{l}\text { Glucose } \\
\text { consumed } \\
(\mathrm{g} / \mathrm{dl})\end{array}$ & $\begin{array}{l}\text { Alanine } \\
\text { (mg/dl) }\end{array}$ \\
\hline Ammonium acetate & 6.6 & 5.0 & 102.0 \\
\hline " bicarbonate & 6.0 & 5.0 & 31.5 \\
\hline chloride & 6.0 & 2.5 & 37.0 \\
\hline lactate & 6.0 & 5.0 & 24.5 \\
\hline phosphate & 6.0 & 5.0 & 66.5 \\
\hline sulfate & 6.4 & 5.0 & 36.0 \\
\hline
\end{tabular}

sources were studied as substitutes of ammonium acetate in the medium. However, no further increase was found. Besides the nitrogen sources described above, ammonium nitrate, potassium nitrate, sodium nitrate, ammonium citrate, ammonium formate, ammonium oxalate and urea have been checked, but they all failed to be nitrogen sources.

The time course of one example of alanine formation is shown in Fig. 1. With the con-

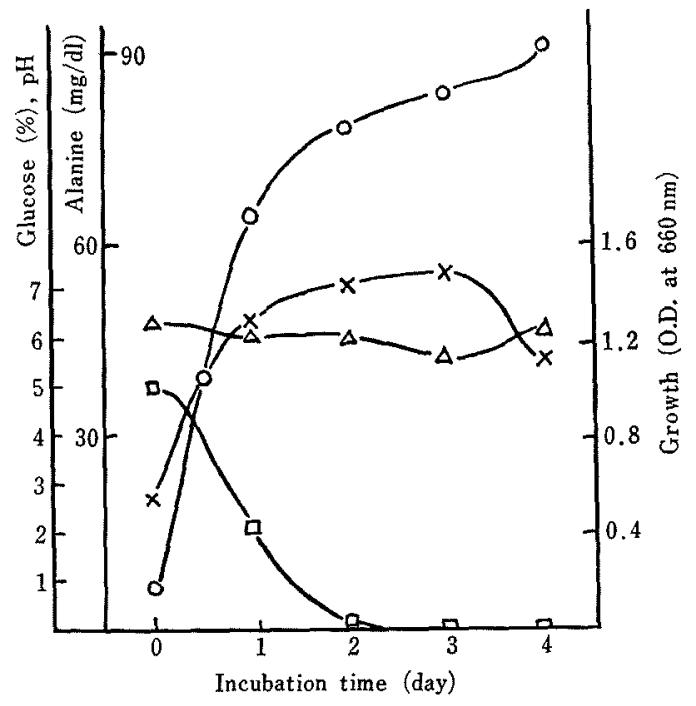

FIG. 1. Time Course of Alanine Formation by Clostridium saccharoperbutylacetonicum.

$\bigcirc-\bigcirc$ Alanine, $\square-\square$ Glucose,

$\triangle-\triangle \mathrm{pH}, \quad \times-\times$ Growth

sumption of glucose the cells grew and alanine was accumulated in $24 \mathrm{hr}$ after inoculation.

Table VI. Relationship of Alanine Formation to Solvent Yields

Each solvent yield was shown as its percentage of initial glucose.

\begin{tabular}{lccccccc}
\hline Medium & $\begin{array}{c}\text { Ammonium } \\
\text { acetate } \\
(\%)\end{array}$ & $\begin{array}{c}\text { Alanine } \\
(\mathrm{mg} / \mathrm{ml})\end{array}$ & $\begin{array}{c}\text { Total } \\
\text { solvent } \\
(\%)\end{array}$ & $\begin{array}{c}\text { Butanol } \\
(\%)\end{array}$ & $\begin{array}{c}\text { Acetone } \\
(\%)\end{array}$ & $\begin{array}{c}\text { Ethanol } \\
(\%)\end{array}$ & $\begin{array}{c}\text { Butanol } \\
\text { Acetone }\end{array}$ \\
\hline TYA & 0.3 & 16 & 36.9 & 29.0 & 6.6 & 1.3 & 4.4 \\
Alanine & 0.5 & 84 & 38.4 & 27.4 & 10.3 & 0.7 & 2.7 \\
Alanine & 1 & 91 & 34.6 & 22.9 & 11.2 & 0.5 & 2.0 \\
\hline
\end{tabular}

Table VII. Relationship of Alanine Formation to Sporulation

Incubations were carried out in anaerobic jars.

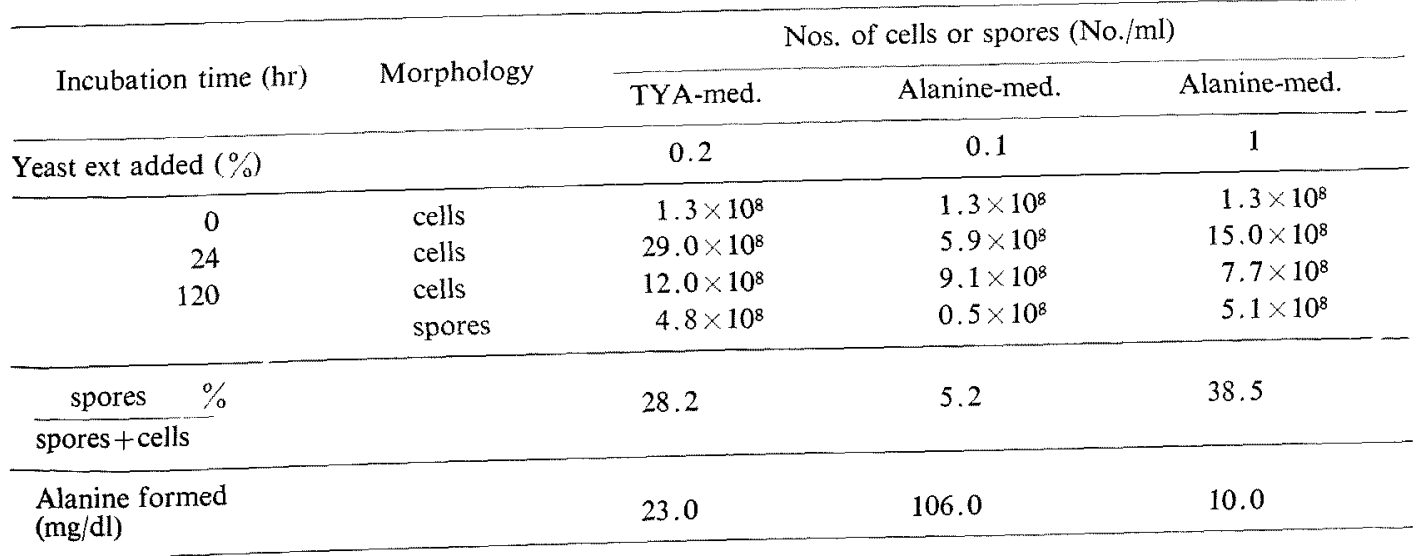




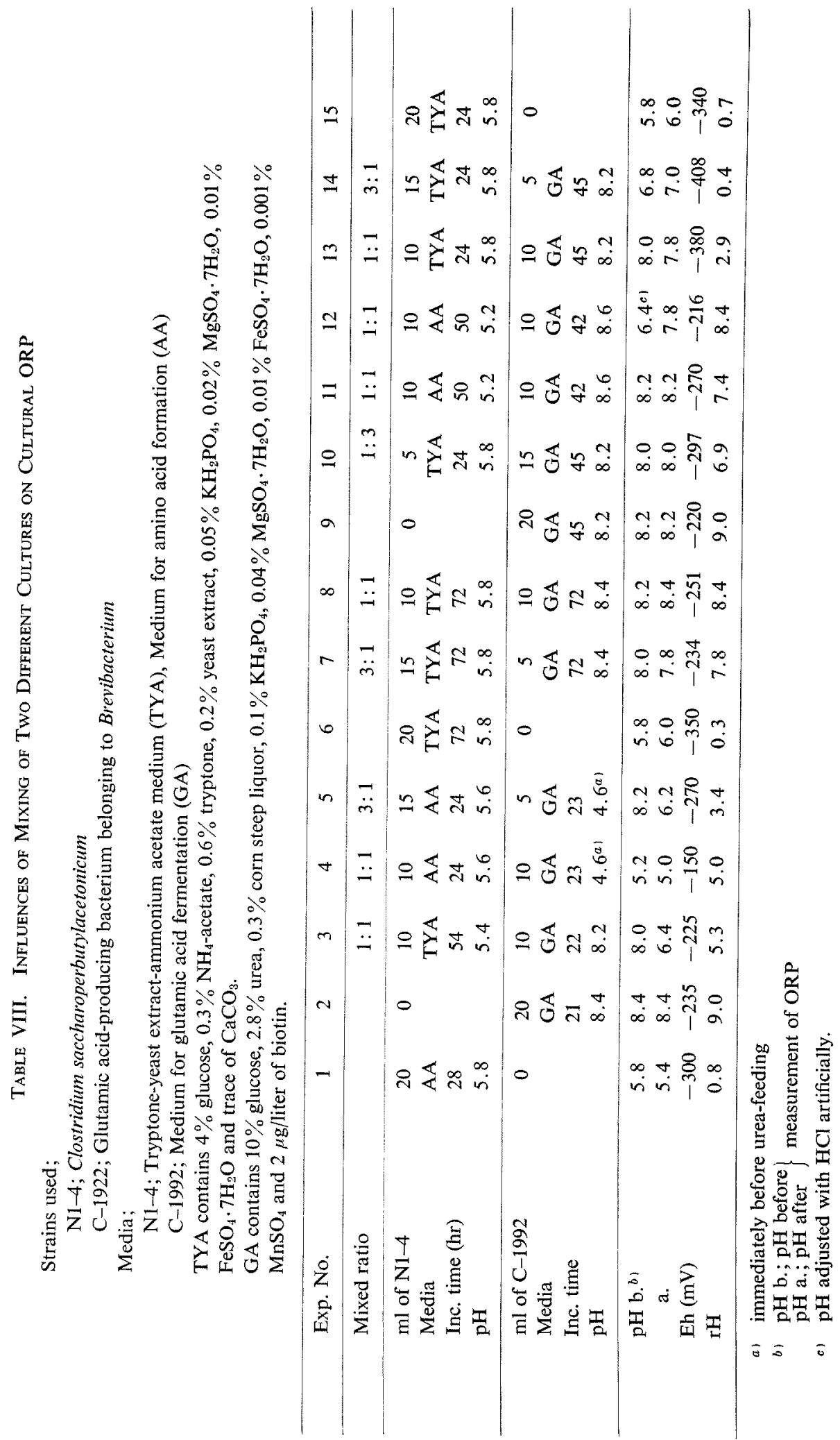


The $\mathrm{pH}$ was maintained in the range of 5.5 to 6.2 throughout the incubation in the presence of calcium carbonate. Fermentation was completed in 2 to 3 days. In 4 day-culture filtrate, not only alanine but small amounts of other amino acids were detected probably as the result of autolysis.

\section{Relationship of alanine formation to solvent yields}

As described before, this strain produced acetone, butanol and ethanol in the medium. These solvent yields were compared in the medium for alanine formation and in the TYA medium as control (Table VI). Total solvent yields showed no remarkable change, whereas the amount of butanol decreased and that of acetone increased when alanine was produced. In other words, the ratio of butanol to acetone decreased from 4.4 to 2.7 or 2.0 . Increase of acetone, however, seemed to result from acetate of ammonium acetate, of which ammonium was used as nitrogen source in the medium.

Relationship of alanine formation to sportation Spore formation was compared in the TYA medium, the alanine medium and the alanine medium containing a high concentration of yeast extract ( $1 \%$, final concentration) (Table VII). A ratio of spores to total numbers of spores plus cells was checked in $120 \mathrm{hr}$-cultures. This ratio was lower in the alanine medium than in the TYA medium or in the alanine medium containing $1 \%$ yeast extract. When alanine was produced at a maximum, spore formation was not active. As alanine is one of the important components in spores, this amino acid was considered to be accumulated extracellularly under the regulation of spore formation. In addition, elongated cells and only small spores were produced in the alanine medium.

\section{Cultural oxidation-reduction potentials (ORP)}

The cultural ORPs of this strain were measured as the control indicator of fermentation. As shown in Table VIII (Exp. Nos. 1, 6, 15), ORP of this culture was maintained between
rH 0.3 and 0.8 .

\section{Influences of mixing of two different cultures on} cultural $O R P$

ORPs of the culture mixed with strain C-1992 which belongs to Brevibacterium and produces L-glutamic acid in the aerobic culture, were investigated. $\mathrm{Cl}$. saccharoperbutylacetonicum (N1-4) showed $\mathrm{rH} 0.3$ to 0.8 during active fermentation. Strain C-1992, on the other hand, showed $\mathrm{rH}$ around 9 (Exp. Nos. 2 and 9). After mixed equally with each other, its ORP was $\mathrm{rH} 5.0$ to 5.3 (Exp. Nos. 3 and 4), almost the average value of these two cultural ORPs. Increasing ratio of the strain N1-4 resulted in a lower $\mathrm{rH}(3.4$, No. 5). In the TYA medium, N1-4 completed the fermentation in about $30 \mathrm{hr}$, therefore, there was no metabolic activity after $72 \mathrm{hr}$. Upon the addition of C1992 to this 72 hr-culture in TYA, the ORP drifted to that of C-1992 and showed $\mathrm{rH} 7.8$ to 8.4 (Nos. 7 and 8 ). When 24 hr-culture in TYA medium of N1-4 was mixed with a large amount of $45 \mathrm{hr}$-culture of C-1992, the ORP drifted towards that of $\mathrm{C}-1992$ and showed rH 6.9 (No. 10). On the other hand, when it was mixed with small amount of $45 \mathrm{hr}$-culture of $\mathrm{C}-1992$, the ORP was close to that of $\mathrm{N1}-4$ culture (rH 0.4, No. 14).

From above results, in the mixed culture, each particular ORP was shown from the strength of metabolic activities of individual microbes.

\section{REFERENCES}

1) M. Hongo and M. Uyeda, Agr. Biol. Chem., 36, 269 (1972).

2) B. Nioman, M. Rarprand and G. N. Cohen, Compt. rend., 225, 700 (1947).

3) M. Hongo, Japanese Patent, 284441 (1961); U.S. Patent, 2945786 (1960); French Patent, 1265840 (1961).

4) M. Hongo, R. Harada, K. Akaboshi, K. Nagata and S. Takahashi, Nippon Nôgeikagaku Kaishi, 39, 247 (1965).

5) M. Hongo and A. Murata, Agr. Biol. Chem., 29, 1135 (1965).

6) Y. Watanabe, K. Watanabe, F. Koide, T. Saito and K. Shimura, Nippon Nôgeikagaku Kaishi, 34, 
$620(1960)$.

7) G. Klein, "Handbuch der Pflanzenanalyze II, Spezielle Analyze I," Wein, 1932, p. 786.
8) M. Hongo, A. Ishizaki and M. Uyeda, Agr. Biol. Chem., 36, 141 (1972). 